\title{
Long-term Trends in Fertility of Soils under Continuous Cultivation and Cereal Cropping in Southern Queensland. I Overall Changes in Soil Properties and Trends in Winter Cereal Yields
}

\author{
R. C. Dalal and R. J. Mayer
}

Queensland Wheat Research Institute, Department of Primary Industries, Toowoomba, Qld 4350.

\begin{abstract}
Changes in fertility of some southern Queensland soils resulting from extended periods of cultivation are presented, together with trends in yields of winter cereals on these soils. Six major soils of the cerealbelt, cropped for maximum periods of 20-70 years were examined. These were: Black earths, Waco soil; grey, brown and red clays (brigalow), Langlands-Logie soil; grey, brown and red clays (poplar box), Cecilvale soil; grey, brown and red clays (belah), Billa Billa soil; grey, brown and red clays (coolibah), Thallon soil; red earths, Riverview soil. Organic matter and its constituents, especially total organic C, organic $\mathrm{C}$ in the light fraction, total $\mathrm{N}$ and mineralizable $\mathrm{N}$, were affected most by cultivation, showing decreases of $19-67 \%$ overall. Other soil properties probably associated with organic matter, including bulk density and DTPA (diethylenetriaminepentaacetic acid) extractable manganese, were also significantly affected by cultivation in all soils.

Soil properties affected least by cultivation were concentrations of inorganic phosphorus, total and exchangeable potassium, calcium carbonate, and dithionite extractable iron and aluminium. Most other soil properties studied (organic $\mathrm{P}$, total sulfur, $\mathrm{pH}$, exchangeable magnesium and sodium, exchangeable sodium percentage, and oxalate-extractable iron and aluminium) were affected by cultivation in at least four soils.

Four factors accounted for $70 \%$ of the total variation among the 45 soil properties considered. They appeared to represent organic matter, clay colloids, iron and aluminium oxides, and soluble salts. Dry matter yield and/or $\mathrm{N}$ uptake of winter cereal crops (wheat and barley) measured in 1983 showed significant decreasing trends with period of cultivation in all soils.
\end{abstract}

\section{Introduction}

Cultivation and cropping of soil affect its chemical, physical, and biological characteristics. Cultivation of a soil previously supporting native vegetation or pasture generally leads to reduced organic matter, organic carbon and nitrogen (Clarke and Marshall 1947; Haas et al. 1957), deterioration in soil structure (Baver 1968), and lower biological activity (Khan 1970). This is primarily due to changes in temperature, moisture fluxes and aeration, to exposure of new soil surfaces resulting from aggregate disruption, to reduced addition of organic materials, and frequently to increased soil erosion.

Long-term effects of cultivation and cropping on soil organic matter have been studied in temperate and Mediterranean environments (Cooke 1967; Russell 1981; Odell et al. 1984), but less so in subtropical and tropical regions. Jenny and Raychaudhuri (1960) observed 60-70\% loss of organic matter from long-cultivated Indian soils. Martin and Cox (1956) found that, in the first 25 years of cultivation, a heavy clay soil (Vertisol) in Queensland lost nitrogen at the rate of $0.8 \%$ per year of the amount in the top $0.15 \mathrm{~m}$. Russell (1981) observed higher $\mathrm{N}$ losses (about 
$5 \%$ per year) from an initially virgin grey brown clay soil (Vertisol) cropped to sorghum continuously for 10 years; sorghum yields also decreased. Other constituents of organic matter such as phosphorus and sulfur also decline with cultivation. Williams and Lipsett (1961) found that approximately $17 \%$ of organic $\mathrm{P}$ and $30 \%$ of organic S were mineralized when soils were cultivated for wheat for 50-60 years.

Exchangeable calcium, magnesium and potassium, and cation exchange capacity of soils are also reduced by long periods of cultivation (Williams and Lipsett 1961). These effects may result partly from loss in organic matter, but differences in water fluxes (downward and upward movement, evaporation and transpiration, infiltration and runoff) due to changes in vegetation upon cultivation may also affect exchangeable cations and salinization in soil.

In temperate soils, deterioration in soil structure with cultivation results in lower aggregate stability (Marshall 1962), higher bulk density (Stephens et al. 1945), and often increased erosion (Stephens et al. 1945). The effects of long-term cultivation on physical properties in subtropical soils are less known.

In Queensland, wheat and barley are grown in winter, and sorghum and sunflower in summer, usually following 6-12 months' fallow, in continuous sequences. Large areas have relatively recently been cleared of native vegetation for cropping, and clearing is continuing. The study reported here and in subsequent papers was aimed at determining how these soils have reacted to such intensive use in a subtropical environment. Understanding of soil fertility trends should indicate more clearly the need for changes in cropping and cultural practices and for research related thereto. Six important soils were examined for changes in chemical, physical and biochemical properties over extended periods of cultivation, and the effect of cropping history on current crop yield was assessed. This paper reports overall changes in soil properties of the top layer $(0-0.1 \mathrm{~m})$ resulting from cultivation and cropping, together with trends in yields of winter cereals in relation to the period of cultivation and cropping.

\section{Materials and Methods}

Location of the study area is shown in Fig. 1. Mean annual rainfall (83-101 year period) for Dalby, Chinchilla, Goondiwindi, Surat and Thallon are 670,630,610, 580 and $480 \mathrm{~mm}$ respectively. Approximately $35 \%$ of annual rainfall is received in winter months (April to September inclusive). The corresponding mean annual temperatures are $18 \cdot 5,19 \cdot 4,19 \cdot 9,20 \cdot 3$ and $20 \cdot 5^{\circ} \mathrm{C}$, respectively. The region and its agricultural potential have been described by Weston et al. (1975).

\section{The Soils}

The soils studied were located as shown in Fig. 1. A general description of the six soil series and the dominant natural vegetation growing on each is given in Table 1 . The Waco and Cecilvale clay soils are described by Beckmann and Thompson (1960) and Reeve et al. (1960), and Langlands and Logie soils are described by Dawson (1972). The profile descriptions of Billa Billa, Thallon and Riverview are given in Appendix 1 (B. Slater, personal communication), and general descriptions of these soils are also given by Isbell (1957) and Galloway et al. (1974). The soils are described briefly below:

Waco. Very deep, black to greyish brown self-mulching, weakly gilgaied, cracking clays with an alkaline reaction trend at depth. The parent material is clay alluvium derived from basalt. Slope is less than $0.5 \%$.

Langlands-Logie. Very deep, ranging from dark greyish brown to dark brown cracking clays which are alkaline at or near the surface and acid at depth. There is a fairly strong gilgai microrelief (shelf to depression, $0 \cdot 2-0 \cdot 4 \mathrm{~m}$ ). Parent material is alluvial clayey sediments formed from light grey shales, silt-stones, and fine to medium sandstones. Slope is less than $1 \%$. 


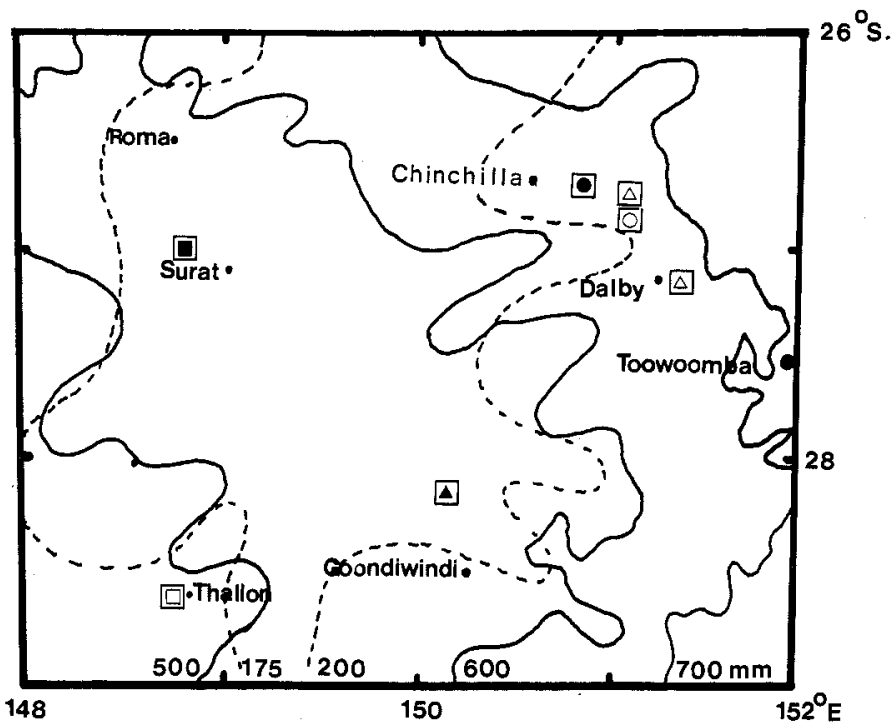

Fig. 1. Map of southern Queensland showing isohyets of mean annual rainfall (-) and winter rainfall (-- ) (Weston 1975). The study areas are located on Waco $(\bigcirc)$, Langlands-Logie $(\bullet)$, Cecilvale $(\triangle)$, Billa Billa (A), Thallon $(\square)$ and Riverview ( $\square$ ) soils.

Table 1. The soils and natural vegetation

\begin{tabular}{|c|c|c|c|c|c|c|}
\hline \multirow[t]{2}{*}{ Soil series } & \multicolumn{3}{|c|}{ Classification } & \multirow[t]{2}{*}{ Soil texture } & \multirow{2}{*}{$\begin{array}{c}\text { Clay } \\
\text { minerals }^{\mathrm{D}}\end{array}$} & \multirow{2}{*}{$\begin{array}{c}\text { Dominant natural } \\
\text { vegetation }\end{array}$} \\
\hline & Great Soil Group ${ }^{A}$ & $\begin{array}{c}\text { Factual } \\
\text { Key }^{B}\end{array}$ & Soil Taxonomy $\mathrm{C}$ & & & \\
\hline Waco & Black earth & Ug 5.16 & Typic Pellusterts & Clayey & $\mathrm{S}, \mathrm{K}, \mathrm{Q}, \mathrm{I}^{\mathrm{E}}$ & Dichanthium sericeum \\
\hline Langlands-Logie & $\begin{array}{l}\text { Grey, brown and } \\
\text { red clays }\end{array}$ & Ug 5.24 & $\begin{array}{l}\text { Typic } \\
\text { Chromusterts }\end{array}$ & Clayey & Q,R.I., $K^{\mathrm{E}}$ & $\begin{array}{r}\text { Acacia harpophylla } \\
\text { Casuarina cristata }\end{array}$ \\
\hline Cecilvale & $\begin{array}{l}\text { Grey, brown and } \\
\text { red clays }\end{array}$ & Ug 5.41 & $\begin{array}{l}\text { Typic } \\
\text { Chromusterts }\end{array}$ & Clayey & R.I.,Q,K, $\mathbf{I}^{\mathrm{E}}$ & $\begin{array}{l}\text { Eucalyptus populnea, } \\
\text { Dichanthium sericeum }\end{array}$ \\
\hline Billa Billa ${ }^{\mathrm{G}}$ & $\begin{array}{l}\text { Grey, brown and } \\
\text { red clays }\end{array}$ & Ug 5.25 & $\begin{array}{l}\text { Typic } \\
\text { Chromusterts }\end{array}$ & $\begin{array}{l}\text { Loamy } \\
\text { clay }\end{array}$ & Q,R.I., K, $\mathbf{I}^{\mathrm{F}}$ & $\begin{array}{l}\text { Casuarina cristata, } \\
\text { Eremophila mitchellii, } \\
\text { Geijera parvifiora }\end{array}$ \\
\hline Thallon $^{\mathrm{H}}$ & $\begin{array}{l}\text { Grey, brown and } \\
\text { red clays }\end{array}$ & Ug 5.24 & $\begin{array}{l}\text { Typic } \\
\text { Chromusterts }\end{array}$ & Clayey & $\mathrm{K}, \mathrm{I}, \mathrm{S}, \mathrm{Q}^{\mathrm{F}}$ & $\begin{array}{c}\text { Eucalyptus microtheca, } \\
\text { Astrebla lappacea, } \\
\text { Acacia pendula }\end{array}$ \\
\hline Riverview & Red earth & $\begin{array}{l}\text { Gn } 2.11 \\
\text { Gn } 2.12\end{array}$ & $\begin{array}{l}\text { Rhodic } \\
\text { Paleustalfs }\end{array}$ & $\begin{array}{l}\text { Sandy } \\
\text { loam }\end{array}$ & $\mathbf{K}, \mathrm{Q}, \mathrm{I}, \mathrm{H}^{\mathrm{F}}$ & $\begin{array}{l}\text { Eucalyptus } \\
\text { melanophloia, } \\
\text { Ermophila mitchellit, } \\
\text { Eucalyptus populnea }\end{array}$ \\
\hline
\end{tabular}

A After Stace et al. (1971). ${ }^{\mathrm{B}}$ After Northcote (1971). ${ }^{\mathrm{C}}$ USDA Soil Survey (1975). ${ }^{\mathrm{D}}$ Minerals in order of decreasing abundance: S, smectite; K, kaolinite; I, illite; Q, quartz; R.I., randomly interstratified; H, Hematite. E J. O. Skjemstad (unpublished data). F Predicted from Gunn (1974): G Also Medpark (Ug 5.24) and TeApiti (Ug 5.33). HAlso Birra Birra (Ug 5.29).

Cecilvale. Deep, greyish brown to black, weakly gilgaied, cracking clays which are alkaline at depth. Parent material is clay alluvium derived from basalt and sandstone. Slope is less than $1 \%$.

Billa Billa. Deep, greyish yellow brown, light medium clays which are alkaline at or near the surface and acid at depth. There is a weak gilgai microrelief $(<0.2 \mathrm{~m})$. Soils are derived from weathered calcareous sediments and occur on a gently undulating (slope $1 \%$ ) landscape. 
Thallon. Deep, brownish black, medium clays with an alkaline reaction trend at depth $(0 \cdot 7-1 \mathrm{~m})$. There is some evidence of incipient gilgai $(0.1 \mathrm{~m}$ deep). Parent material is Quaternary argillaceous alluvium. Slope is less than $1 \%$.

Riverview. Deep, dark reddish brown, sandy clay loams, neutral to acid in reaction. They occur on a very gently undulating landscape (slope 1\%). Parent material is weathered ferruginized sediments.

\section{Crop Management Practices}

The period of cultivation, number of winter and/or summer crops per year, rate of fertilizer applications, stubble retention and number of cultivation operations per year were tabulated from farmers' records (Table 2). Winter crops were wheat $(90 \%)$, barley $(9 \%)$ and oats $(1 \%)$ and summer crops were sorghum $(90 \%)$ and sunflower $(8 \%)$. In recent years cultivation operation during the fallow period have consisted typically of one or two each with a chisel plough, sweep plough and scarifier, and occasionally a disc plough. In the earlier years (before approximately 1960) greater use was made of disc implements and in some instances mouldboard ploughs were employed for primary tillage. The number of cultivation operations in the study area appears to follow mean annual rainfall, presumably reflecting the need to control weeds. The use of fertilizer (mainly anhydrous ammonia, urea and monoammonium phosphate) is restricted to the Dalby (Waco and Cecilvale) and Chinchilla (Langlands-Logie) areas.

\section{Soil Sampling}

Soil samples were collected, generally during April-July, from farmers' fields that had been under cultivation for 0.5-70 years, and from an adjacent area that had never been cultivated. The samples were taken at $0-0 \cdot 1,0 \cdot 1-0 \cdot 2,0 \cdot 2-0 \cdot 3,0 \cdot 3-0 \cdot 6,0.6-0.9$ and $0.9-1 \cdot 2 \mathrm{~m}$ depths by a hydraulically operated sampler with a $46 \mathrm{~mm}$ diameter cutting edge.

Representative soil samples were obtained at each site by sampling 0.1 ha areas on a $5 \mathrm{~m}$ by $8 \mathrm{~m}$ grid. This grid pattern was followed even in gilgai areas because separate sampling of shelf and depression areas was not feasible due to partial levelling of the gilgais during cultivation. From a preliminary investigation it was found that representative samples were obtained in this manner. Five samples, each from $0-0 \cdot 1,0 \cdot 1-0.2$ and $0.2-0.3 \mathrm{~m}$ depths, and two samples, each from $0 \cdot 3-0 \cdot 6$, 0.6-0.9 and $0 \cdot 9-1 \cdot 2 \mathrm{~m}$, were mixed to obtain composite samples at respective depths. Five composite samples were obtained from each depth. The soil samples were sealed in plastic bags in the field and stored at $4^{\circ} \mathrm{C}$ until further processing.

Soil moisture content was determined by drying a subsample at $105^{\circ} \mathrm{C}$ for $24-48 \mathrm{~h}$. The field bulk density was calculated from the oven-dried soil weight contained in the field volume of the soil sample. The remainder of the soil sample was dried at $25^{\circ} \mathrm{C}$ in a forced-draught oven, ground to pass a $2 \mathrm{~mm}$ sieve $(0.25 \mathrm{~mm}$ sieve for organic $\mathrm{C}$ and total $\mathrm{N}$ determination) and stored in sealed plastic containers.

\section{Plant Sampling}

Plant samples of winter crops were collected in 1983 from the areas where soil samples had been obtained, by harvesting 10 quadrats $\left(0.5 \mathrm{~m}^{2}\right.$ each) at maturity. Dry matter yields were obtained by drying the plant samples at $80^{\circ} \mathrm{C}$ for $24-48 \mathrm{hr}$. Grain and straw were then separated, weighed, ground to pass a $1 \mathrm{~mm}$ sieve and stored in sealed plastic containers.

\section{Analytical Techniques}

Total soil organic $\mathrm{C}$ and that in the light fraction (density $<2.0 \mathrm{Mg} \mathrm{m}^{-3}$ ) were determined by the Walkley and Black method adapted for spectrophotometric determination (Sims and Haby 1971). The light fraction was obtained by a slightly modified procedure of Richter et al. (1975), and the sample was dried at $80^{\circ} \mathrm{C}$ for at least $6 \mathrm{~h}$. Total $\mathrm{N}$ in soil was determined by the Kjeldahl method (Bremner 1965), and that in the plant material by the procedure described by Jackson (1958). Total P, sulfur, potassium and zinc in soil were determined by X-ray fluorescence spectrometry. Organic $\mathrm{P}$ was determined by the ignition procedure of Saunders and Williams (1955). Calcium carbonate was estimated by loss in soil weight upon addition of $\mathrm{HCl}$ containing $\mathrm{FeCl}_{2}$ (Bauer et al. 1971). Oxalate and dithionite extractable aluminium and iron in soil were determined according to Schwertmann (1964) and Asami and Kumada (1960), respectively.

Soil $\mathrm{pH}$ and electrical conductivity measurements were made in $1: 5$, soil: $\mathrm{H}_{2} \mathrm{O}$, suspension. Total cation exchange capacity and exchangeable cations were estimated by the displacement method using alcoholic $\mathrm{NH}_{4} \mathrm{Cl}$ at $\mathrm{pH} 8 \cdot 5$ (Loveday 1974); calcium, magnesium, sodium and potassium in the displaced solution were determined by atomic absorption spectrophotometry. 


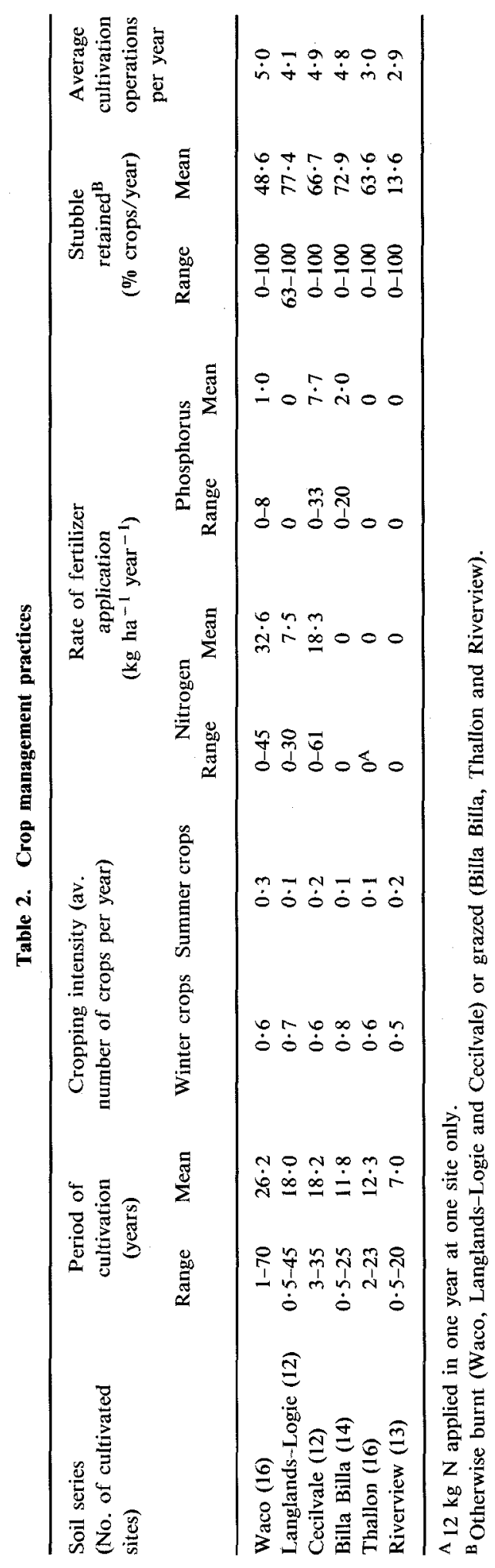


Nitrate- $\mathrm{N}$ was determined colorimetrically (Best 1976) in $2 \mathrm{M} \mathrm{KCl}$ extracts obtained from air-dried soil (1:10, soil:solution). Negligible amounts of $\mathrm{NH}_{4}-\mathrm{N}$ were present. Biologically mineralizable $\mathrm{N}$ was obtained by the procedure described by Keeney (1982). Sodium bicarbonate (pH 8.5) extractable $\mathbf{P}$ $\left(\mathrm{NaHCO}_{3}-\mathrm{P}\right.$ ) (Colwell 1963 ) and DTPA (diethylenetriaminepentaacetic acid) extractable manganese, zinc and copper were also determined (Lindsay and Norvell 1978).

Urease activity was assayed by the procedure of Douglas and Bremner (1971) by incubating the soil and urea reaction mixture at $37^{\circ} \mathrm{C}$ for $3 \mathrm{~h}$.

Clay, silt and sands were determined by the pipette method (Day 1965). Also measured were dispersion index $[100 \times(<2 \mu \mathrm{m}$ soil dispersed in water after $1 \mathrm{~h}$ end-over-end shaking $) /$ total clay, $<2$ $\mu \mathrm{m})]$ and aggregation index [100 - $(100 \times<20 \mu \mathrm{m}$ soil dispersed in water after $1 \mathrm{~h}$ end-over-end shaking)/(total clay + silt, $<20 \mu \mathrm{m})$ ]. In Vertisols, the bulk density measured at field moisture content was adjusted for 'normal' shrinkage up to the moisture content at field capacity (Berndt and Coughlan 1976; Yule and Ritchie 1980; Berndt, personal communication).

\section{Statistical Analysis}

Overall changes in soil properties were studied by paired ' $t$ ' tests (Snedecor and Cochran 1967), and trends in dry matter yields and $\mathrm{N}$ uptake with increasing period of cultivation were determined by regression analysis. Factor analysis, with a varimax rotation of the factors, was used to suggest sources of common variation among the soil properties (Rummel 1970).

\section{Results and Discussion}

\section{Changes in Soil Properties}

The properties most affected by cultivation in all six soil series were organic $\mathrm{C}$, total $\mathrm{N}$, total $\mathrm{C}$ in the light fraction, mineralizable N, DTPA extractable Mn and bulk density (Table 3). The first three properties are components of soil organic matter. Mineralizable $\mathrm{N}$ also expresses the biological activity of the soil, and bulk density is one measure of the soil's physical condition. DTPA-extractable manganese probably includes $\mathrm{Mn}$ associated with organic matter as well as exchangeable manganese (Randall et al. 1976; Shuman 1979). Therefore, those properties affected most by cultivation in these six soils are all associated with soil organic matter. The precise relationship of soil organic matter and its distribution in the light fraction, sand, silt and clay fractions of these soils series with the variable periods of cultivation is examined in detail in subsequent papers.

Overall decline in organic carbon (Table 3) ranged from $19 \%$ in Thallon soil to $45 \%$ in Langlands-Logie soil; the corresponding total $\mathrm{N}$ losses were $25-45 \%$. There were larger losses, however, in total $C$ in the light fraction (25-67\%) and mineralizable $\mathrm{N}(39-57 \%)$. Thus, as well as a decline in total quantity of organic matter, the nutrient-supplying capacity decreased at an even faster rate with cultivation. Tiessen and Stewart (1983) showed similar faster declines in labile fractions of organic matter than in total organic matter when virgin soils were cultivated.

The decrease in DTPA-extractable manganese ranged from $25 \%$ in Riverview soil to $70 \%$ in Cecilvale soil. Overall increase in bulk density ranged from $13 \%$ in Riverview soil to $28 \%$ in Cecilvale soil (Table 3). Although bulk density measured at a field moisture content was corrected for 'normal' shrinkage in Vertisols from that at field capacity (Berndt and Coughlan 1976; Yule and Ritchie 1980), it is likely that all Vertisols do not shrink normally. However, Coughlan (1984) observed this normal (three-dimensional) shrinkage behaviour in a large number of Vertisols from Darling Downs and central Queensland. As shown later (Table 6), the changes in DTPA-extractable manganese and bulk density upon cultivation were at least partly associated with losses in organic matter upon cultivation. 


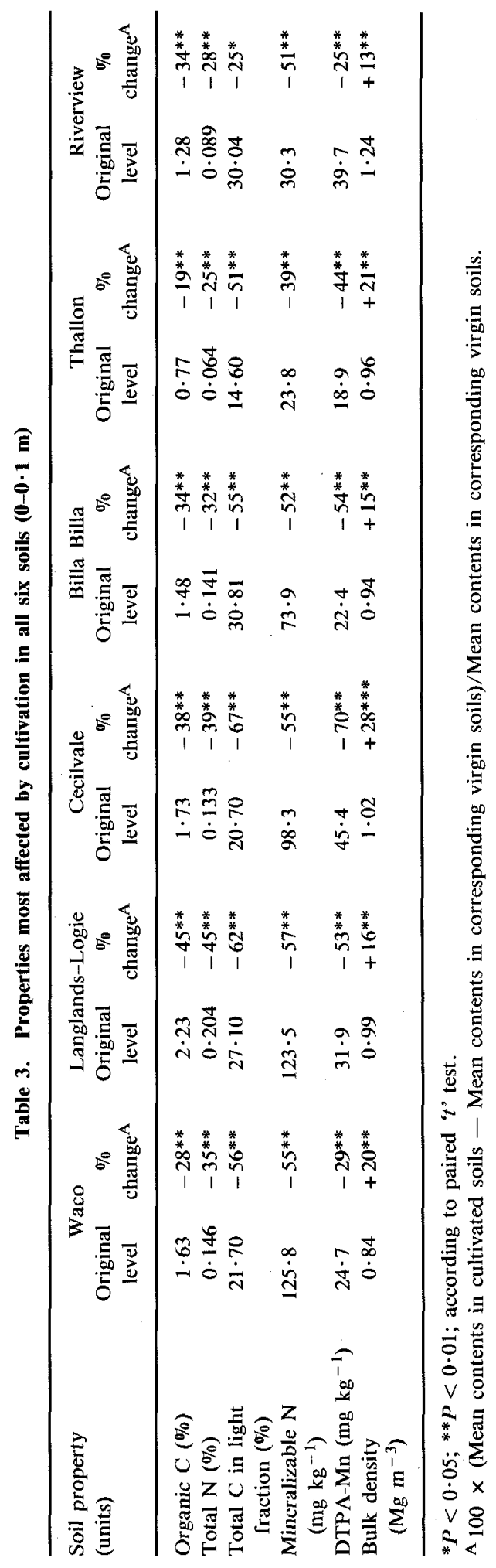


Soil properties moderately affected by cultivation are listed in Table 4 . The organic $\mathrm{P}$ and total $\mathrm{S}$ (inorganic $\mathrm{S}$ constituted $<10 \%$ of total $\mathrm{S}$ ), oxalateextractable $\mathrm{Fe}$ and DTPA-extractable $\mathrm{Cu}$, generally decreased upon cultivation in at least four soils. The first two are the constituents of soil organic matter (Williams 1962), and the latter two are either chelated or stabilized by organic matter in soil (McKeague and Day 1966; Lindsay and Norvell 1978).

The effect of cultivation on soil $\mathrm{pH}$, exchangeable $\mathrm{Mg}$ and oxalate extractable Al did not follow similar trends in all soils (Table 4). Exchangeable $\mathrm{Na}$ and exchangeable sodium percentage (ESP) were generally higher in cultivated than virgin soils. This may have been due to changes in cation exchange capacity (Williams 1962), water fluxes, and salt movement in the soils (Shaw and Yule 1978). The significant increases in exchangeable sodium (27-36\%) and ESP (27-42\%) with cultivation and their future trends require further study because of the likely salinization of soils in semiarid subtropical environments.

Nitrate-N concentration was higher in four of the cultivated soils than in corresponding virgin soils, reflecting the stimulating influence of fallow tillage on $\mathrm{N}$ mineralization. Besides, in Waco and Cecilvale soils, nitrate- $\mathrm{N}$ concentration may also have been influenced by fertilizer $\mathrm{N}$ input. However, the Langlands-Logie soil had a high nitrate- $\mathrm{N}$ concentration, even under its native brigalow vegetation (Table 4).

One consequence of the higher mineralizable $\mathrm{N}$ in soil, especially in the early years of cultivation, is the rapid increase in nitrate- $\mathrm{N}$ content which usually exceeds crop requirements, thus providing the opportunity for surplus nitrate to be leached below the rooting zone (Wetselaar and Norman 1960). This was demonstrated for the Billa Billa soil (Dalal 1984), where nitrate-N accumulated at the rate of $29 \mathrm{~kg}$ $\mathrm{N} \mathrm{ha}^{-1}$ year ${ }^{-1}$ at $0 \cdot 6-1 \cdot 2 \mathrm{~m}$ depth in the first 12 years of cultivation.

Soil properties generally affected least by cultivation were $\mathrm{C} / \mathrm{N}$ ratio (except Waco), inorganic $\mathrm{P}$, total $\mathrm{K}$ and exchangeable $\mathrm{K}$ (except Langlands-Logie), $\mathrm{CaCO}_{3}$ content, dithionite-extractable aluminium, dithionite-extractable iron (except Riverview) and urease activity (except Waco) (Table 5). The effect of cultivation on urease activity in the top layer $(0-0.1 \mathrm{~m})$ is complicated by changes in temperature, moisture and substrate (available C) during the year (Dalal 1985).

Clay contents $(0-0 \cdot 1 \mathrm{~m})$ of virgin and cultivated soils were essentially similar in Waco, Thallon and Riverview soils, but they were slightly higher in cultivated Langlands-Logie (49\% cf. 52\%), Cecilvale $(40 \%$ cf. $46 \%)$ and Billa Billa soils $(34 \%$ cf. $40 \%)$, possibly because deeper soil $(0.1 \mathrm{~m})$ was mixed with the topsoil by cultivation or because of removal of topsoil containing lower clay content by erosion. For this reason, and because deeper layers also have effects on crop growth, changes in soil properties with cultivation are considered on the basis of the whole profile in studies to be reported later.

Because of the large number of soil properties measured to discern trends in fertility upon cultivation and cropping, factor analysis was used to suggest sources of common variation among the soil properties (Table 6). The properties were grouped among four factors, factors I, II, III, and IV, representing properties associated with or affected by organic matter, clay and inorganic colloids, iron and aluminium oxides, and soluble salts, respectively, which together accounted for $70 \%$ of the total variance. It can be seen from Tables 3 and 6 that factor I, soil 


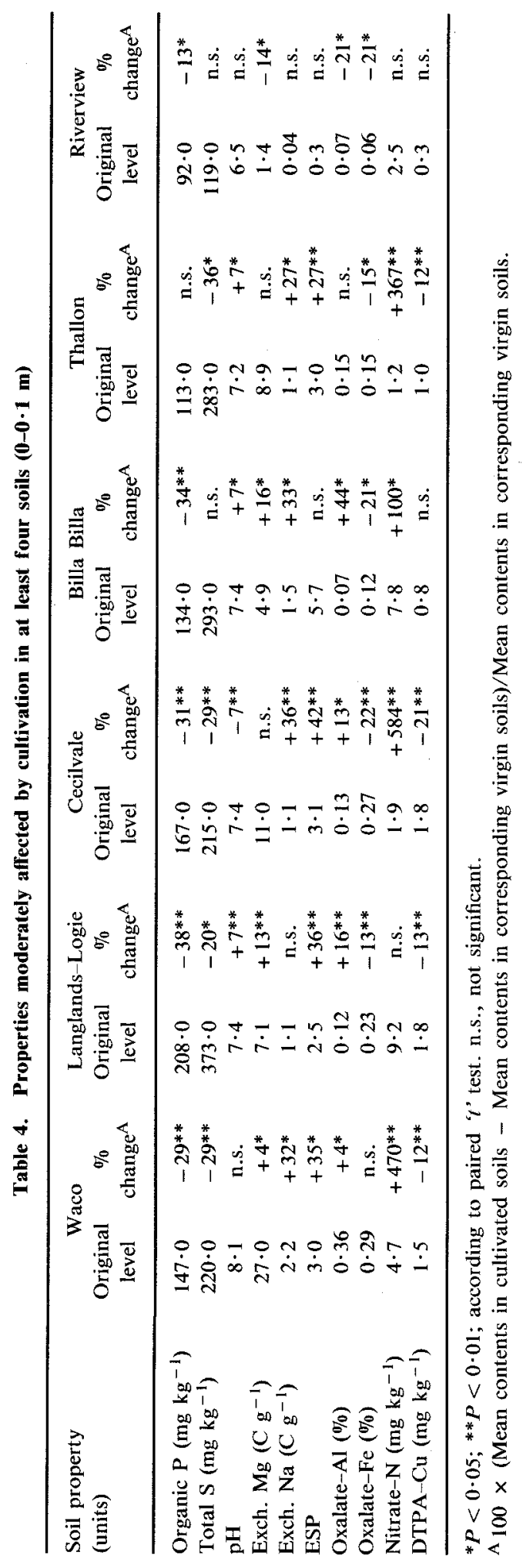




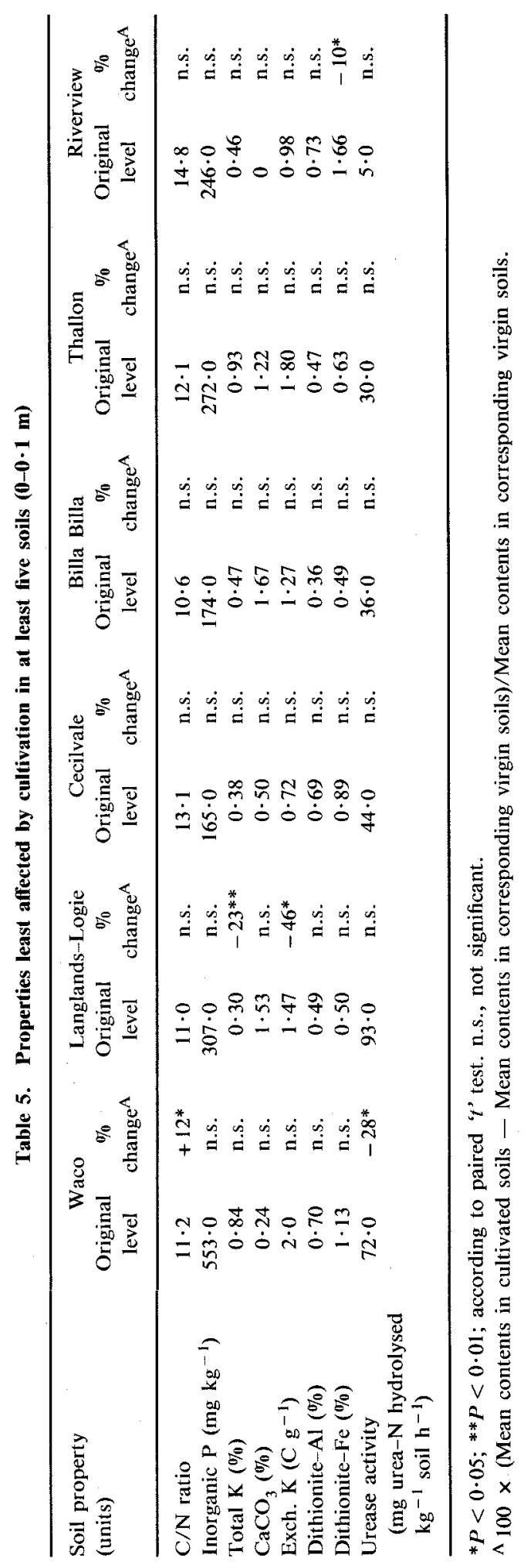


organic matter, is affected most by cultivation in these soils, and in view of the vital role of organic matter in nutrient element release and maintenance of soil structure, it is clear that the dynamics of organic matter need to be studied in greater detail.

\section{Yield Trends}

Total dry matter yield and $\mathrm{N}$ uptake by winter cereals (mainly wheat), generally decreased with increasing periods of cultivation (Fig. 2). Significant relationships between the dry matter yield and period of cultivation were obtained in Waco, Billa Billa, Thallon and Riverview soils. The decreases in dry matter yields were $1.8 \%$, $2 \cdot 3 \%$ and $8 \cdot 5 \%$ per year in Waco, Billa Billa and Thallon soils, respectively. In Riverview, a quadratic relationship was obtained, maximum yield being obtained after 3 years' cultivation (Fig. 2). Grain yield trends were essentially similar to those for dry matter, although relationships with period of cultivation were less significant.

Table 6. Factor loadings of selected soil properties (0-0.1 $\mathrm{m}$ depth)

\begin{tabular}{lccccc}
\hline Soil property & \multicolumn{2}{c}{ Factors $^{\mathrm{A}}$ : } & & & \\
& I & II & III & IV & Communality \\
\hline Organic C & 0.95 & & & & 0.96 \\
Total N & 0.95 & & & & 0.95 \\
Organic P & 0.73 & & & & 0.65 \\
Total S & 0.57 & & -0.45 & & 0.59 \\
Mineralizable N & 0.88 & & & & 0.87 \\
NaHCO $-P$ & 0.40 & 0.30 & & & 0.56 \\
DTPA-Cu & 0.42 & 0.52 & & & 0.53 \\
DTPA-Zn & 0.33 & & & & 0.38 \\
DTPA-Mn & 0.38 & -0.33 & 0.45 & -0.31 & 0.61 \\
Clay & & 0.95 & & & 0.95 \\
Exch. Ca & & 0.91 & & & 0.85 \\
Exch. Mg & & 0.90 & 0.30 & & 0.93 \\
Exch. Na & & 0.71 & & 0.55 & 0.69 \\
ESP & & & -0.47 & 0.67 & 0.43 \\
EC & 0.43 & & & 0.77 & 0.62 \\
pH & & 0.70 & & 0.43 & 0.78 \\
Dithionite-Fe & & & 0.85 & & 0.78 \\
Dithionite-Al & & & 0.85 & & 0.69 \\
Inorganic P & & 0.53 & 0.34 & & 0.50 \\
Bulk density & -0.43 & -0.50 & & & 0.56 \\
\hline
\end{tabular}

\footnotetext{
A Factor loadings $\geqslant 0.30$ only are reported. Factors I, II, III and IV, respectively, may be assigned to organic matter, clay and inorganic colloids, iron and aluminium oxides and soluble salts.
}

Total $\mathrm{N}$ uptake also decreased with increasing period of cultivation (Fig. 2). N uptake declined at the rate of $2 \cdot 3 \%, 1 \cdot 7 \%$ and $2 \cdot 4 \%$ per year in Waco, Langlands-Logie and Billa Billa soils respectively.

In a study of this nature where crop yields are determined by many factors, it would be difficult to isolate a single factor or group of factors controlling yield (Hallsworth 1969). In the semi-arid environment of the region investigated, water is usually the most limiting factor in crop production. However, in 1983 when the yields in Fig. 2 were obtained, winter rainfall was approximately twice the mean 
for the study area, and so water would have imposed a less serious limitation on yield. Soil properties, such as nutrient supplying capacity, physical conditions and biological activity (possibly including disease), would have had a clearer influence than usual on yields. Therefore, the general trends towards decreasing yields with increasing period of cultivation (Fig. 2) probably reflects the effect of more dominant soil characteristics on crop yields.

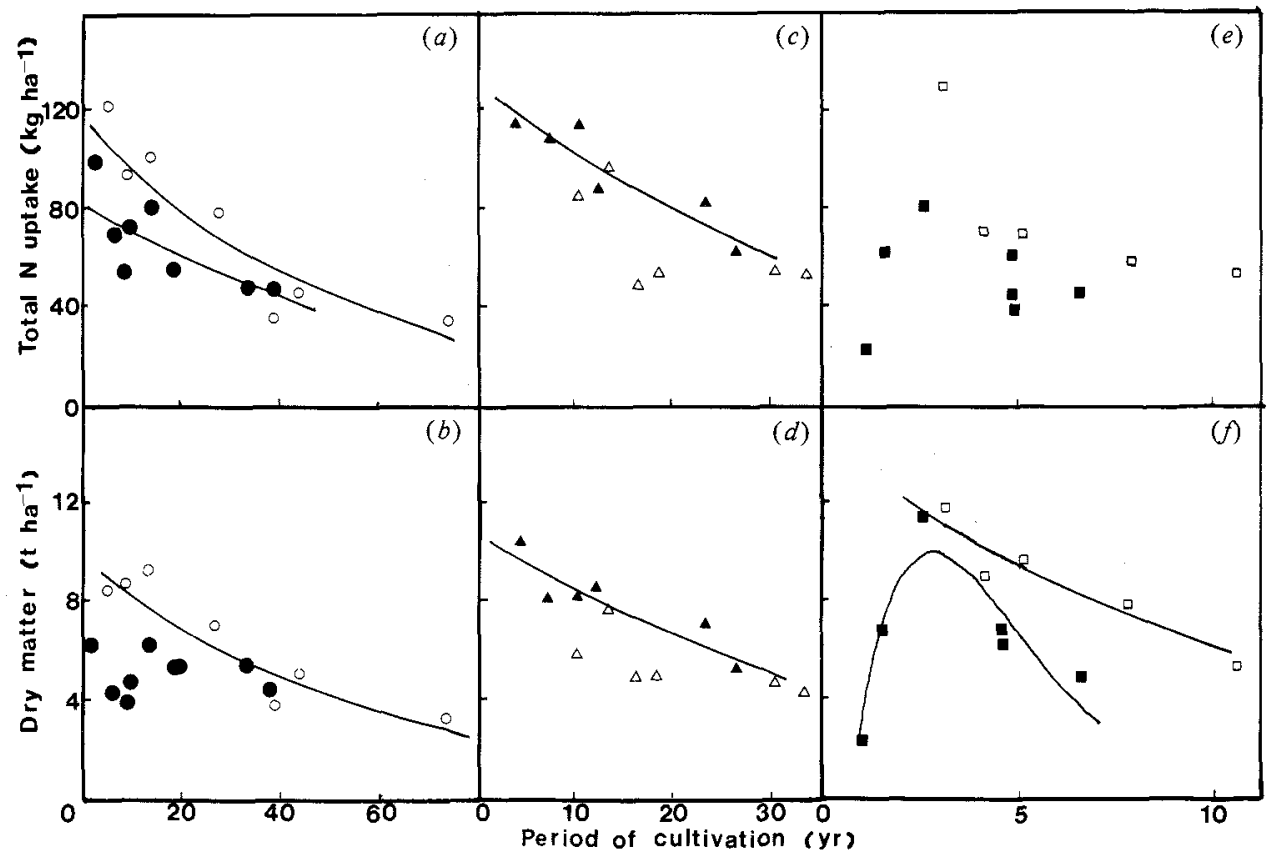

Fig. 2. Total $N$ uptake (N) and dry matter (DM) yields (winter cereals) for 1983 in relation to period of cultivation $(x)$ in six soil series. Symbols are as in Fig. 1. Curves are drawn according to the following regression relationships:
(a) Waco: $y(\mathrm{~N})=126 \cdot 4 \exp (-0.023 x), r=-0.95^{* *}$;
(C) Langlands-Logie: $y(\mathrm{~N})=84.4 \exp (-0.017 x), r=-0.75^{*}$;
(b) $\bigcirc \mathrm{Waco}, y(\mathrm{DM})=9 \cdot 84 \exp (-0.018 x), r=-0.93^{* *}$;
(c) A Billa Billa: $y(\mathrm{~N})=130 \cdot 4 \exp (-0.024 x), r=-0.92^{* *}$;
(d) A Billa Billa: $y(\mathrm{DM})=10.63 \exp (-0.023 x), r=-0.89^{*}$;
(e) $\sqsupset$ Thallon: $y(\mathrm{DM})=14.43 \exp (-0.085 x), r=-0.95^{* *}$;
(f) Riverview: $\ln y(\mathrm{DM})=2 \cdot 2+14 \cdot 9 \ln x-7 \cdot 6(\ln x)^{2} ; r=0 \cdot 91^{* *}$;
$* P<0.05 ; * * P<0.01$.

Soil properties, such as organic $\mathrm{C}$, total $\mathrm{N}$, total $\mathrm{C}$ in light fraction, mineralizable N, DTPA-Mn and bulk density are most affected by cultivation (Table 3 and factor I, and possibly factor III in Table 6). Since these properties also affect crop yields and long-term soil fertility, detailed studies on their dynamics in cultivated soils were undertaken. Further results of this aspect are reported in subsequent papers.

\section{Acknowledgments}

We are grateful to the following farmers for their cooperation in soil and plant sampling and providing previous crop records:

L. Bailey, P. Bock, C. Burcher, C., D. and J. Condon, V. and A. Dawson, A. Fabian, R. and M. Hemming, J. Jobling, H. and G. Ladewig, E. Morris, G. Ross, 
T. Sands, D. and R. Schmelzer, C. Seis, R. and T. Sipple, I. Sperling, J. St. Clair, W. Sullivan, R. Tate, N. Thrupp, and V. York. Technical assistance was provided by D. Orange, J. Glasby, G. Manning and A. Pumfrey at Queensland Wheat Research Institute, Toowoomba, and by officers of Agricultural Chemistry Branch, Indooroopilly. We wish to thank Messrs R. Berndt, J. O. Skjemstad and B. Slater for use of their unpublished data, and Drs A. L. Clarke, W. M. Strong and G. D. Smith for suggestions during this study. Messrs P. Wylie, A. Hamilton, G. Bolton and $\mathbf{J}$. Gray assisted in selection of sampling sites. Financial assistance was provided by the Queensland Wheat Industry Research Committee.

\section{References}

Asami, T., and Kumada, K. (1960). Comparison of several methods for determining free iron in soils. Soil Plant Food (Tokyo) 5, 179-83.

Bauer, H. P., Beckett, P. H. T., and Bie, S. W. (1972). A rapid gravimetric method for estimating calcium carbonate in soils. Plant Soil 37, 689-690.

Baver, L. D. (1968). The effect of organic matter on soil structure. Pontif. Acad. Sci. Scripta Varia 32, 383-403.

Beckmann, G. G., and Thompson, G. H. (1960). Soils and land use in the Kurrawa area, Darling Downs, Queensland. CSIRO Aust. Soils Land Use Ser. No. 37.

Berndt, R. D., and Coughlan, K. J. (1976). The nature of changes in bulk density with water content in a cracking clay. Aust. J. Soil Res. 12, 27-37.

Best, E. K. (1976). An automated method for the determination of nitrate-nitrogen in soil extracts. $Q l d$ J. Agric. Anim. Sci. 33, 161-6.

Bremner, J. M. (1965). Total nitrogen. In 'Methods of Soil Analysis, Part 2'. (Ed. C. A. Black.) pp. 1149-72. (Am. Soc. Agron.: Madison, Wisc.)

Clarke, G. B., and Marshall, T. J. (1947). Influence of cultivation on soil structure and its assessment in soils of variable mechanical composition. J. Counc. Sci. Ind. Res. Aust. 20, 162-75.

Colwell, J. D. (1963). The effects of fertilizers and season on the yield and composition of wheat in southern New South Wales. Aust. J. Exp. Agric. Anim. Husb. 3, 51-61.

Cooke, G. W. (1967). 'The Control of Soil Fertility.' pp. 197-215. (Crosby Lockwood: London.)

Coughlan, K. J. (1984). The structure of Vertisols. In 'Properties and Utilization of Cracking Clay Soils'. (Eds. J. W. McGarity, E. H. Hoult, and H. B. So.) pp. 87-96. Reviews in Rural Science No. 5, University of New England, Armidale, N.S.W.

Dalal, R. C. (1984). Chronosequential depth distribution of nitrate in cultivated grey and brown clays under semi-arid environment. Proc. National Soils Conference, Brisbane, p. 222.

Dalal, R. C. (1985). Distribution, stability, kinetic, and thermodynamic characteristics of urease activity in a Vertisol profile. Aust. J. Soil Res. 23, 49-60.

Dawson, N. M. (1972). Land inventory and technical guide, Jandowae area, Queensland. Qld Dep. Prim. Ind. Div. Land Util. Tech. Bull. No. 3.

Day, P. R. (1965). Particle fractionation and particle-size analysis. In 'Methods of Soil Analysis, Part 1'. (Ed. C. A. Black.) pp. 545-67. (Am. Soc. Agron.: Madison, Wisc.)

Douglas, L. A., and Bremner, J. M. (1971). A rapid method of evaluating different compounds as inhibitors of urease activity in soils. Soil Biol. Biochem. 3, 309-15.

Galloway, R. W., Gunn, R. H., Pedley, L., Cocks, K. D., and Kalma, J. D. (1974). Lands of the Balonne-Maranoa area, Queensland. CSIRO Aust. Land Res. Ser. No. 33.

Gunn (1974). Soils of the Balonne-Maranoa area, South-Central Queensland. CSIRO Aust. Div. Land Use Res. Tech. Memo. 74/1.

Haas, H. J., Evans, C. E., and Miles, E. F. (1957). Nitrogen and carbon changes in Great Plains soils as influenced by cropping and soil treatments. U.S. Dep. Agric. Tech. Bull. No. 1164.

Hallsworth, E. G. (1969). The measurement of soil fertility. J. Aust. Inst. Agr. Sci. 35, 78-89.

Isbell, R. F. (1957). The soils of the Inglewood-Talwood-Tara-Glenmorgan region. Qld Bur. Investig. Tech. Bull. No. 5.

Jackson, M. L. (1958), 'Soil Chemical Analysis.' (Prentice-Hall: Inglewood Cliffs, N.J.)

Jenny, H., and Raychaudhuri, S. P. (1960). Effect of climate and cultivation on nitrogen and organic matter reserves in Indian soils, pp. 1-146. Indian Council of Agric. Res., New Delhi. 
Khan, S. U. (1970). Enzyme activity in a grey wooded soil as influenced by cropping systems and fertilizers. Soil Biol. Biochem. 2, 137-9.

Keeney, D. R. (1982). Nitrogen - availability indices. In 'Methods of Soil Analysis'. (Part 2, 2nd Ed.) (Ed. A. L. Page.) pp. 711-33. (Am. Soc. Agron.: Madison, Wisc.)

Lindsay, W. L., and Norvell, W. A. (1978). Development of a DTPA soil test for zinc, iron, manganese, and copper. Soil Sci. Soc. Am. J, 42, 421-8.

Loveday, J. (1974). Methods for analysis of irrigated soils. Tech. Comm. No. 54, Common. Bur. of Soils, Harpenden, Herts.

Marshall, T. J, (1962). The nature, development, and significance of soil structure. Trans. Joint Meeting Comm. IV and V, Int. Soc. Soil Sci., New Zealand, pp. 243-57.

Martin, A. E., and Cox, J. E. (1956). Nitrogen studies on black soils from Darling Downs, Queensland. I. Seasonal variations in moisture and mineral nitrogen fractions. Aust. J. Agric. Res. 7, 169-83.

McKeague, J. A., and Day, J. H. (1966). Dithionite- and oxalate-extractable Fe and $\mathrm{Al}$ as aids in differentiating various classes of soils. Can. J. Soil Sci. 46, 13-22.

Northcote, K. H. (1971). 'A Factual Key for the Recognition of Australian Soils.' (Rellim Technical Publications: Glenside, S.A.)

Odell, R. T., Melsted, S. W., and Walker, W. M. (1984). Changes in organic carbon and nitrogen of Morrow plot soils under different treatments, 1904-1974. Soil Sci. 137, 160-71.

Randall, G. W., Schulte, E. E., and Corey, R. B. (1976). Correlation of plant manganese with extractable soil manganese and soil factors. Soil Sci. Soc. Am. J. 40, 282-7.

Reeve, R., Thompson, C. H., and Beckmann, G. G. (1960). The laboratory examination of soils from the Toowoomba and Kurrawa areas, Darling Downs, Queensland. CSIRO Aust. Div. Soils Div. Rep. $1 / 60$.

Richter, M., Mizuno, I., Aranguez, S., and Uriarte, S. (1975). Densimetric fractionation of soil organomineral complexes. J. Soil Sci. 26, 112-18.

Rummel, R. J. (1970). 'Applied Factor Analysis.' (Northwestern University Press: Evanston, Illinois.)

Russell, J. S. (1981). Models of long term soil organic nitrogen change. In 'Simulation of Nitrogen Behaviour of Soil-Plant Systems'. (Eds M. J. Frissel and J. A. van Veen.) pp. 222-32. (Centre for Agricultural Publishing and Documentation: Wageningen.)

Saunders, W. M. H., and Williams, E. G. (1955). Observations on the determination of total organic phosphorus in soils. J. Soil Sci. 6, 254-67.

Schwertmann, U. (1964). Differenzierung der Eisenoxide des Bodens durch Extraktion mit Ammonium oxalat-Losung. Z. Pfanzenern. Dung. Bodenkunde 105, 194-202.

Shaw, R. J., and Yule, D. E. (1978). The assessment of soils for irrigation, Queensland. Agric. Chem. Branch Tech. Rep. No. 13. Qld Dep. Prim. Ind., Brisbane.

Sims, J. R., and Haby, V. A. (1971). Simplified colorimetric determination of soil organic matter. Soil Sci. 112, 137-41.

Shuman, L. M. (1979). Zinc, manganese and copper in soil fractions. Soil Sci. 127, 10-17.

Snedecor, G. W., and Cochran, W. G. (1967). 'Statistical Methods.' 6th Edn. (Iowa State University Press: Ames.)

Soil Survey Staff. (1975). Soil Taxonomy. U.S. Dep. Agric., Agric. Handb. No. 436.

Stace, H. C. T., Hubble, G. D., Brewer, R., Northcote, K. H., Sleeman, J. R., Mulcahy, J. J., and Hallsworth, E. G. (1968). 'A Handbook of Australian Soils.' (Rellim Technical Publications: Glenside, S.A.)

Stephens, C. G., Herriot, R. 1., Downes, R. G., Langford-Smith, T., and Acock, A. M. (1945). A soil, land use and erosion survey of part of County Victoria, South Australia. Coun. Sci. Ind. Res, Bull. No. 188.

Tiessen, H., and Stewart, J. W. B. (1983). Particle-size fractions and their use in studies of soil organic matter: II. Cultivation effects on organic matter composition in size fractions. Soil Sci. Soc. Am. J. 47, 509-14.

Weston, E. J., Nason, C. N., and Armstrong, R. D. H. (1975). Resources study in the Condamine-Maranoa basin of Southern Queenșland. Qld J. Agric. Anim. Sci. 32, 1-192.

Wetselaar, R., and Norman, M. J. T. (1960). Recovery of available soil nitrogen by annual fodder crops at Katherine, N.T. Aust. J. Agric. Res. 11, 693-704.

Williams, C. H. (1962). Changes in nutrient availability in Australian soils as a result of biological activity. J. Aust. Inst. Agric. Sci. 28, 196-205.

Williams, C. H., and Lipsett, J. (1961). Fertility changes in soils cultivated for wheat in southern New South Wales. Aust. J. Agric. Res. 12, 612-20. 
Yule, D. F., and Ritchie, J. T. (1980). Soil shrinkage relationships of Texas Vertisols: 1. Small cores. Soil Sci. Soc. Am. J. 44, 1285-91.

Manuscript received 8 April 1985, accepted 16 October 1985

\section{Appendix 1. Profile morphology (B. Slater, unpublished data)}

\section{Billa Billa clay}

Depth (mm)

A11 0-50

\section{Description}

A12 50-200 Greyish yellow brown (10YR4/2); medium clay; moderate 10-20 mm angular

Greyish yellow brown (10YR4/2); light medium clay; moderate $2-5 \mathrm{~mm}$ granular; moderately moist; moderately weak. Field $\mathrm{pH} 7 \cdot 5$ Clear to blocky; moist, moderately weak. Clear to -

B21 200-300 Greyish yellow brown (10YR4/2) medium clay; moderate 20-50 mm lenticular; moist, moderately weak. Field $\mathrm{pH} 8 \cdot 9$. Gradual to -

B22 300-700 As for B21 but includes very few fine carbonate nodules. Field pH $8 \cdot 0$. Gradual to -

B23 700-850 Brown (7.5YR4/3); medium heavy clay; moderate 20-50 mm lenticular; moist, moderately weak. Gradual to -

B24 850-1350 Dull brown (7.5YR5/3); medium clay; moderate 20-50 mm prismatic; moist, moderately weak; very few fine manganiferous veins. Field $\mathrm{pH} 7 \cdot 8-7 \cdot 0$. Gradual to -

B25 1350-1500 Dull brown (7.5YR5/4) medium clay; moderate 20-50 mm prismatic; moderately moist, moderately firm; very few fine manganiferous veins. Field $\mathrm{pH} 6 \cdot 2$.

$\mathrm{C} 1500+$ Orange (7.5YR6/7) massive friable sandstone.

Thallon clay Depth (mm)

A11 0-60

\section{$\underline{\text { Description }}$}

Brownish black (10YR3/2); medium clay; moderate 2-5 mm granular; moist, moderately weak; field $\mathrm{pH} 8 \cdot 0$. Clear to -

A12 60-200 Greyish yellow brown (10YR4/2); medium clay; moderate 10-20 mm angular blocky; moist, moderately weak. Gradual to -

B21 200-700 Greyish yellow brown (10YR4/2); medium heavy clay; moderate $20-50 \mathrm{~mm}$ lenticular; moist, moderately weak. Field $\mathrm{pH} 8 \cdot 2-8 \cdot 8$. Gradual to -

B22 700-1000 Greyish yellow brown (10YR5/2); medium heavy clay; moderate $10-20 \mathrm{~mm}$ lenticular; moist, moderately weak. Field $\mathrm{pH} 9 \cdot 0$. Gradual to -

B23 1000-1500 Dull yellowish brown (10YR5/3) medium clay; moderate 20-60 mm prismatic breaking to moderate $20-50 \mathrm{~mm}$ lenticular; dry, moderately strong; few fine gypsum crystals. Field pH $8 \cdot 5-8 \cdot 0$.

\section{Riverview sandy loam}

Depth (mm)

A11 $0-100$

A12 100-180

B21 $180-800$

B22 800-1050

B23 $1050-1350$

C $1350+$

\section{Description}

Dark reddish brown (5YR3/4); sandy loam; massive; dry, moderately weak. Field $\mathrm{pH} 6 \cdot 0$. Diffuse to -

Dark reddish brown (2.5YR3/3); sandy loam; massive; dry, moderately weak. Clear to -

Reddish brown (2.5YR4/6); light sandy clay loam; weak 10-20 mm angular blocky; moist, moderately weak. Field $\mathrm{pH} 5 \cdot 8-6 \cdot 0$. Gradual to -

Reddish brown (2.5YR4/6); sandy clay loam; moist, moderately weak. Field pH $6 \cdot 2$ Diffuse to -

Reddish brown (2.5YR4/6); clay loam, sandy; weak 10-20 mm angular blocky; wet, moderately weak. Field $\mathrm{pH} 6 \cdot 2$. Gradual to -

Reddish brown (5YR4/6) with orange red and grey mottles; sandy clay weathered sediments massive; dry, very firm. Field pH $6 \cdot 8$.

Small amounts of fine quartz gravel occur throughout the profile. 